\title{
EARNINGS MANAGEMENT IN BANKING INDUSTRY AND ITS IMPACT ON THE FIRM VALUE
}

\author{
Ahmad Abbas \\ IAIN Parepare \\ ahmad.abbas@stainparepare.ac.id
}

Received: $28-05-2018$

\section{ABSTRACT}

This research investigates earnings management through discretionary accruals in pre and post period of convergence of IFRS and analyses its impact on the firm value in Indonesian banking industry. The sample of this research was 23 banks listed in

Revisied: 22-09-2018

Accepted: $14-10-2018$ Indonesia Stock Exchange over period of 2007-2014. The method of this research is quantitative. The data are analyzed using the non-paramateric Wilcoxon Signed Ranks and the multiple regression. The result of this research found that accrual earnings management has no the mean difference in pre and post period of convergence of IFRS. Based on the effect of earnings management on banking firm value, it was found that banking earnings management has an impact on the increase of the firm value. This research further identifies the patterns in accrual earnings management including income-increasing and income-decreasing. Both patterns induced managers to increase the firm value. This research also found that that income-decreasing pattern has a stronger impact on the increase of the firm value than income-increasing pattern.

Keywords: Earnings Management; Firm Value; IFRS; Income-Increasing; IncomeDecreasing.

How to cite: Abbas, A. (2018). Earnings Management In Banking Industry And Its Impact On The Firm Value. Akrual: Jurnal Akuntansi. 10 (1): 69-84.doi: http://dx.doi.org/10.26740/jaj.v10n1.p69-84

\section{INTRODUCTION}

The banking industry is often excluded from the sample of earnings management researches because its characteristics are viewed different with the other firms. It really operates with strong bounds and regulations and has different accrual processes that are not likely to be captured well by accrual models. However, those are only a defense. Earnings management should not be ignored to be more analysed. Banks are likely to have prudential regulations imposed by central bank. In a certain condition, managers occasionally have the way to lead firm value to be more profitable.
The existing earnings management in the banking industry can emerge because the constraint in regulation, such as related to capital adequacy ratio or high incentive on bonus scheme (Healy and Wahlen, 1999; Cheng et al., 2011). Earnings management based on accrual model could actually have been identified from the change of depreciation method or the estimation of provision on loan losses and charge off. Some studies have focused on accruals as a tool for capturing earnings managment in the banking industry (Tobing and Anggorowati, 2009; Oosterbosch, 2009). A few studies also investigate the effects of IFRS 
AKRUAL: Jurnal Akuntansi, volume 10, issue 1, October 2018 (69-84)

implementation on the level of earnings management based on accrual in the banking industry. In European countries where IFRS was adopted starting 2005, Oosterbosch (2009) found a decrease in the level of earnings management. In Indonesia, it has also been investigated by Anggraita (2012) who finds a decrease in the level of earnings management through loan loss provision after the convergence of IFRS and Santy et al. (2013) through discretionary accruals as proxy of earnings management who find no effect at all. inconsistency of their research is a reason to be conducted further research. Understanding studies of Anggraita (2012) and Santy et al. (2013), both actually have the limitation in the use of data period in which they take into consideration period of 2009 and 2010 as cut-off in pre and post implementation of IFRS in banking industry. Consequently, the research related to earning management in pre and post of implementation of IFRS has possibly not had the fixed effect for being concluded. Based on the suggestion of Anggraita (2012), data should be selected and collected at least three or five periods. Hence, this research is called to fulfill it.

An increasing number of studies focus on the determinants of earnings management (Abaoub, 2013; Manzalawy and Rwegasira, 2013; Rezaei and Roshani, 2012). A number of recent scholars also document evidence on the relationship between earnings management and firm value (Omid, 2012; Raoli, 2013; Sayari et al., 2013), but they have fundamentally not reached the patterns in earnings management consisting of income-increasing and incomedecreasing. Therefore, another possible extension given by this research is an examination of the patterns of earning management to see whether they have positive or negative effects on the firm value and which one pattern has a strong impact on the firm value.

Earnings management is occasionally pointed out in a negative way so that its effect is linked with corporate governance (Abdallah, 2018; Alishah, 2009; Anggraita, 2012; Lin, 2011; Marchini et al., 2018; Salleh and Haat, 2014) or moderated by corporate governance (Tangjitprom, 2013; Vajriyanti et al., 2015). However, it is not always perceived in the opportunistic behaviour. There are two behaviours of managers to practice earnings management which are opportunistic and efficient behaviours (Scott, 2009). Earnings management can be beneficial or harmful for firm value based on how managers employ their behaviours. Managers with the opportunistic side come from bad earnings management and should be negative for firm value and managers with the efficient side come from good earnings and should be positive for firm value (Tangjitprom, 2013). This research does not view earnings management as opportunism that managers report earnings opportunistically to maximize their own utility, but it views earnings management in perspective of efficiency that managers attempt to avoid inefficiency of the firm value. Therefore, managers are likely to 
attempt to increase firm value in a perspective of efficiency.

This research aims to investigate earnings management through accrual model in pre and post of IFRS in Indonesian banking industry. It then analyses earnings management patterns consisting of income-increasing and incomedecreasing and their impact on the firm value. This research contributes to the literature by providing consistent evidence in terms of earnings management and IFRS and by discussing earnings management proposition emphasizing on the efficient behaviour. In addition, there are no studies utilising research design related to accrual earnings management patterns (income-increasing and incomedecreasing) and their impact on banking firm value so that this research also provides more extensive finding in understanding manager's behaviour. Moreover, the banking industry area is less explored by scholars in earnings management context.

\section{LITERATURE REVIEW}

\section{Agency Theory and Earnings Management}

Earnings management is the choice of a manager of accounting policies so as to achieve some specific objectives (Scott, 2009). Managers will choose policies to maximize their own utility or interest of their principal utility. In this sense, earnings management can be categorized into opportunistic or efficient behaviour. It is viewed as the opportunistic purpose because managers attempt to mislead shareholders about the firm value using their judgment in the financial report. In other word, managers who are agents to the principal act to their own self-interest. Agency concept implied by Jensen and Meckling (1976) fundamentally explains the relationship between principal and agent in opportunistic perspective. In the opportunistic perspective, managers act in their own selfinterest at the expense of owners and have access to information not available to owners which raise information asymmetry to the owners (Deegan, 2007).

Conversely in managerial behaviour with the purpose of efficiency, managers attempt to improve earnings information to protect themselves and to anticipate unpredictable occurrence for the sake of firms. Hence, earnings management can be good if used responsibly. Discretionary accrual management is a way to reveal credibly firm's inside information in terms of earnings expectations (Scott, 2009). In the efficient perspective, organisations will seek to put in place mechanisms to align the interest of agent with the interest of the principal. Mechanisms are put in place up front with the objective of the firm value. Sayari et al. (2013) highlight efficiency in earnings management that correlation between information and stock market is noticeable. Accounting modification which has no impact on cash flows can not bring about any information to the market as it has no effect on investor's prediction and expectations.

Accounting methods may be selecting the most efficient way to portray the performance of the firm. In efficient perspective as implied by 
AKRUAL: Jurnal Akuntansi, volume 10, issue 1, October 2018 (69-84)

Deegan (2007) that accounting practices adopted by firms are often explained on the basis of the true image of financial performance of the firm. Earnings management might be perceived that managers could be employing their behaviours with the purpose of keeping good image for themselves.

For the banking industry, Indonesian financial accounting standard statements had been revised into basis on IFRS beginning on 2010 which are PSAK 50 and PSAK 55 in terms of financial instruments. Those emphasize any objective evidence on impairment losses (loss event). Once impairment loss has been recognized on a financial asset recognized at cost, it is not permitted to recognize a reversal. The criteria that there is objective evidence of impairment loss includes significant financial distress, default or delinquency in interest or principal payments, or observable data indicating that there is a measurable decrease in the estimated future cash flows from a portofolio of financial assets. PSAK 50 and PSAK 55 currently emphasize that loan loss provision is estimated individual and collective and requires probability data of defaults and historical losses at least three years. Considering the nature of IFRS, loan loss provision would be less effective for the banking management in manage earnings. This is likely to affect earnings management through loan loss provision. For the case of the banking industry, Oosterbosch (2009) found that IFRS reduces earnings management taking into consideration loan loss provision. In this sense, earnings management proxied by discretionary accruals which taking into consideration loan loss provision is likely to differ after the convergence of IFRS. For initial examination, accrual earnings management seems different pre and post convergence of IFRS. The mean difference for accrual earnings management in post period of convergence of IFRS is lower than in pre period of convergence of IFRS.

H1. There is the difference in the mean for accrual earning management between pre and post period of convergence of IFRS

\section{Earnings Management and Banking Firm} Value

A number of studies pointed out earnings management from the opportunistic behaviour of managers and found evidence that the firm value decreases in earnings management. Managers use earnings management as a tool to gain to themselves. Hence, earnings management has harmful or negative effect on the firm value. Cornett et al. (2009) documented that when reported earnings between the upper and lower bounds are set by performance based contracts and performance based compensation is more sensitive to reported earnings, managers may persistently manage earnings upward rather than smoothing earnings. From another point view, some studies provide evidence to support earnings management. It has beneficial impacts on the increase of the firm value are obtained (Jiraporn, 2008; Sayari et al., 2013). In this sense, it derives from efficient earnings management perspective. Managers could be engaging in earnings management to support the 
increase of the firm value. In perspective of efficiency, the relationship between information and stock market is noticeable (Sayari et al., 2013). Information is supposed to be reflected in stocks and not accounting value in itself. Stock value is the estimator of the firm's real unobservable value (Dumontier and Raffournier, 2000). It can be a parameter which validates all accounting data.

Phenomenon of earnings management in banking industries is caused by likelihood of national monetary authorities (central bank). Banking regulations requires regulatory capital ratios to measure capital adequacy to identify the firm value. As consequence, banks with low capital ratios are likely to lead an increase in level of the firm value through accruals. In addition, Cheng et al. (2008) states that a number of banks have incentives to reduce earnings volatility by decreasing income for banks with more increased performance or increasing income for bank with more decreased performance. They can also employ earnings management within legitimate constraint to reduce the volatility of earnings. Reduced volatility can represent lower risk (Oosterbosch, 2009).

Bank managers have incentives to use their loan loss provision to manage earnings and regulatory capital as well as to communicate private information about future prospect (Ahmed et al., 1999). Discretionary of loan loss provision is used as the main instrument for earnings management in the form of whether income-increasing or income-decreasing.
Wijayanti and Diyanty (2017) found that there is an effect of loan loss provision on the earnings before tax. In the condition in which the decreased earnings, the banking managers are suspected to have the incentive to postpone the expense of loan loss.

Mostafa (2017) documented that discretionary accruals are positive and significantly higher for firms with low operating performance than those for firms with high operating performance. If earnings management is efficient, then discretionary accruals will have a significant positive relationship with profitability and if it is opportunistic, discretionary accruals will have a significant negative relationship with profitability (Omid, 2012). In terms of earnings management, study of Raoli (2013) utilised earnings management through income-increasing and income-decreasing. It documented that an increase in firm value is associated with income-increasing and a decrease in firm value is associated with income-decreasing. Tangjitprom (2013) states that good earnings management is expected to use beneficial methods and should be positive for firm value. It can further be started from an examination of types of earnings management (income-increasing accruals, income-decreasing accruals, etc). This research is interested in investigating income-increasing and incomedecreasing patterns. In income-increasing pattern, firms manage earnings upward with consideration of reporting the positive valuation of the earnings. In income-decreasing pattern, firms manage earnings downward. When 
AKRUAL: Jurnal Akuntansi, volume 10, issue 1, October 2018 (69-84)

earnings of the future period will be downward, it can be managed using earnings of the past period

This research initially expects that the practice of earnings management through accruals leads managers to increase the firm value. It further employes income-increasing and income-decreasing as patterns of earnings management. First, the expectation of this research is that managers engage in incomeincreasing as efficiency of utility leading to an increase of the firm value. Managers occasionally communicate more information about the firm value. There is no less revealed to owners because managers do not act for their own utility or in their opportunistic behaviours. When managers forecast firm value going down, they are led to employ income-increasing to increase the firm value. Managers attempt to improve firm value to protect themselves and to anticipate unpredictable occurrence for the sake of firms. As a result, income-increasing is managed to increase the firm value.

\section{H2a. Firm value increases in income-increasing}

By using negative discretionary accruals as the proxy from income-decreasing, the finding of Raoli (2013) documented a decrease in firm value is associated with incomedecreasing meaning that when managers see the firm value going down, they have incentive to manipulate earnings downward. In different perspective, this research is still proposition in efficient behaviour of managers so that incomedecreasing is not viewed from opportunistic behaviours. When managers forecast firm value more going up, they are induced to employ income-decreasing. Managers are likely to smooth their firm value because their performance seems good in the eyes of principle. As a result, the hypothesis is also predicted that income-decreasing is managed by bank managers to sustain high firm valuation. In other word, an increase in income-decreasing induces managers to engage in sustaining the positive valuation of the firms.

\section{H2b. Firm value increases in income-decreasing}

\section{RESEARCH METHODS}

\section{Sample Selection}

The process of selecting the sample is started from 33 banks listed in Indonesia Stock Exchange over period of 2007-2014. Then, this research excludes merger and acquisition and eliminates banks with incomplete data. As a result, final sample is 23 banks with 161 bankyear observations.

\section{Variable Measurement}

\section{Earnings Management}

Earnings management is proxied by discretionary accruals estimated using Beaver and Engel model (1996). It involves loan loss provision. Beaver et al. (1989) that investors would understand the rise of loan loss provision as the power signal of banking industry. Bank managers also have incentives to use these loan loss provisions to manage earnings and regulatory capital as well as to communicate or signal regarding private information as future prospects (Ahmed et al., 1999). Loan loss 
provision is a relatively large accrual for banks and therefore have a significant impact on earnings (Oosterbosch, 2009). The approach based on discretionary accruals is relevant for the banking industries.

$\mathrm{TA}_{\mathrm{it}}=\mathrm{DA}_{\mathrm{it}}+\mathrm{NDA}_{\mathrm{it}}$

Furthermore, TA is estimated using the regression equation:

$\mathrm{TA}_{\mathrm{it}}=\alpha+\beta_{1} \mathrm{CO}_{\mathrm{it}}+\beta_{2} \mathrm{LOAN}_{\mathrm{it}}+\beta_{3} \mathrm{NPA}_{\mathrm{it}}+$

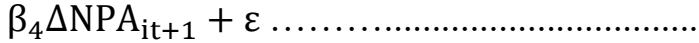

To obtain coefficients, all variables are already deflated by GBV. Having obtained coefficient of regression equation, NDA could be obtained from the following equation:

$\mathrm{NDA}_{i \mathrm{t}}=\alpha+\beta_{1} \mathrm{CO}_{\mathrm{it}}+\beta_{2} \mathrm{LOAN}_{\mathrm{it}}+\beta_{3} \mathrm{NPA}_{\mathrm{it}}+$

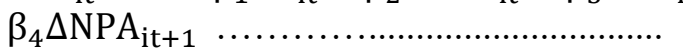

Thus, discretionary accruals could be obtained from the following equation:

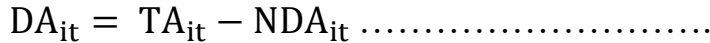

Where, TA is total accrual, DA is discretionary accrual, NDA is non discretionary accrual, $\mathrm{CO}$ is loans charge-offs, LOAN is loans outstanding, NPA is non performing asset, $\triangle \mathrm{NPA}$ is change of non performing assets which is difference non performing assets between $t+1$ and $t$, and GBV is equal to equity plus total allowance for loan losses.

\section{Firm Value}

Firms value proxied by Tobin's $\mathrm{Q}$ is a ratio devised by James Tobin of Yale University measured as total market value of firm divided by total asset value. The market value of equity plus debt is used to calculate total market value of firm present the firm's future growth. Market value of equity can be calculated by multiplying current price with total shares. If Tobin's $Q$ is greater than 1, then the market value is greater than the value of the firm's recorded assets. The firm is overvalued. This suggests that the market value reflects some unmeasured or unrecorded assets of the firm. High Tobin's Q values encourage firms to invest more in capital because they are worth more than the price they paid for them. If Tobin's $Q$ is less than 1 , the market value is less than the regerded value of the assets of the firm. This suggests that the market may be undervaluing the firm. As a result, if $\mathrm{Q}$ is greater, it indicates that the firm has succeeded to achieve more performance, but if it is less than Tobin's Q, firm needs to improve its performance. (3)

\section{Control Variable}

Several control variables maditionally identified in the literature as correlated with independent variable. Corporate governance, listing status age, and firm size are included into this research. Corporate governance has the effect on firm value (Akdogan and Boyacioglu, 2014; Ararat et al., 2014; Hussein and Venkatram, 2013; Mansur and Tangl, 2018; Mardnly et al., 2018; Salleh and Haat, 2014; Tornyeva and Wereko, 2012). In this research, corporate governance is proxied by board of commissioner and audit committee. The existences of board of commissioners and audit committee become the adequate evidence of improving the firm value. They are statistically valid to be proxy of corporate governance shown table 1 below. 
AKRUAL: Jurnal Akuntansi, volume 10, issue 1, October 2018 (69-84)

Table 1. Confirmatory factor analysis

\begin{tabular}{lcc}
\hline & $\begin{array}{c}\text { Cut- } \\
\text { off }\end{array}$ & Value \\
\hline Kaiser-Meyer-Olkin (KMO)Test & $\geq 0.50$ & 0.50 \\
$\chi 2$ (Chi- Square) & & 53.42 \\
\multicolumn{1}{c}{ Sig. Probability } & $\leq 0.05$ & 0.000 \\
Eigen Value & $>1.00$ & 1.53 \\
Cummulative Variance & $\geq 60.0$ & 76.74 \\
Cummulative Variance Anti Image & $\geq 0.50$ & 0.50 \\
\hline Source: Data Process & &
\end{tabular}

Furthermore, firm age and size have been identified as attributes having an impact on the growth of the firm value. Listing status age is measured using the number of years since listed on Indonesia Stock Exchange and firm size is measured using natural logarithm of total assets. This research also includes IFRS as additional control variable because the firm value as independent variabel is likely to be affected by the period of convergence of IFRS. It is given 0 for pre period of convergence of IFRS and 1 for post period of convergence of IFRS.

\section{Model Specification}

This research is designed to analyse accrual earnings management and then its relation to the firm value. First, it investigates accrual earnings management in pre and post period of convergence IFRS. This is related to the first hypothesis. The period IFRS is divided into pre and post period of convergence of IFRS. To investigate the mean difference, this research should use equal proportion of the sample. Hence, pre period of convergence IFRS is composed by bank-year observation from 2007 to 2009 and post period of convergence IFRS is composed bank-year observation from 2010 to 2012. The reason of conducting cut-off in 2010 is that IFRS has revised Indonesian financial accounting standard statements in 2010 which are PSAK 50 and PSAK 55.

Second, by using all bank-year observations from 2007 to 2014, this research then examines the relationship between accrual earnings management and the firm value. This is related to the second hypothesis. This research takes into consideration two patterns in accrual earnings management context which are incomeincreasing and income-decreasing. Hence, two models are provided to analyse the relationship between accrual earnings management and the firm value. Study of Raoli (2013) designs the income-increasing using positive accruals and the income-decreasing using negative accruals. Understanding this sense, this research also creates a portofolio of banks considering income-increasing and income-decreasing by including only those with positive discretionary accruals for income-increasing (model 1) and with negative discretionary accruals for incomedecreasing (model 2).

\section{Statistical Analysis}

This research employes descriptive statistics, univariate analysis, and multivariate analysis. For descriptive statistics, it presents mean, median, minimum, maximum, and standard devision along with a number of observation for each of the variables. To test the hypothesis 1 , statistical analysis uses univariate test. The significance of the difference accrual earnings management between pre and post IFRS is 
tested using a non-parametric Wilcoxon signed ranks.

To test the hypothesis 2 , this research uses multivariate analysis. The initial equation to test the relationship between accrual earnings management and the firm value of banks is shown as follows.

$\mathrm{Q}=\alpha+\beta_{1} \mathrm{DA}+\beta_{2} \mathrm{CG}+\beta_{3}$ LISTING + $\beta_{4}$ SIZE $+\beta_{5}$ IFRS $+\varepsilon$

The hypothesis 2 consists two parts. Model 1 is related to the income-increasing testing hypothesis 2a. To test it, this research only includes positive discretionary accrual.

$\mathrm{Q}=\alpha+\beta_{1} \uparrow \mathrm{DA}+\beta_{2} \mathrm{CG}+\beta_{3}$ LISTING + $\beta_{4}$ SIZE $+\beta_{5}$ IFRS $+\varepsilon \ldots \ldots \ldots \ldots \ldots \ldots$.

Model 2 is related to the incomedecreasing testing hypothesis $2 \mathrm{~b}$ and only includes negative discretionary accrual. The equation to test the hypothesis $2 b$ is shown as follows

$\mathrm{Q}=\alpha+\beta_{1} \downarrow \mathrm{DA}+\beta_{2} \mathrm{CG}+\beta_{3}$ LISTING + $\beta_{4}$ SIZE $+\beta_{5}$ IFRS $+\varepsilon$

Where $\mathrm{Q}$ is firm value, DA is accrual earnings management, $\uparrow \mathrm{DA}$ is incomeincreasing, $\downarrow \mathrm{DA}$ is income-decreasing, $\mathrm{CG}$ is corporate governance, LISTING is listing status age, SIZE is size firm, and IFRS is dummy convergence of IFRS.

After testing each the hypothesis $2 \mathrm{a}$ and $2 \mathrm{~b}$, the correlation analysis is required to investigate strength each of the patterns in accrual earnings management which one of patterns has highly strong correlation on the firm value.

\section{ANALYSIS AND DISCUSSION}

Table 2 shows descriptive statistics and test statistics regarding accrual earnings management in pre and post period of IFRS. Panel A describes the descriptive statistics using equal proportion of the sample. It composes bank-year observation from 2007 to 2009 and bank-year observation from 2010 to 2012. Accrual earnings management in pre period of IFRS obtains the the mean of 0.0028 and in post period of IFRS obtains the mean of -0.0643 . The difference in the mean is significant at 0.864 level as shown in Panel B. In the level of minimum and maximum, bank managers conduct discretionary accruals in pre period of IFRS higher than in post period of IFRS.

Table 2. Accrual earnings management in pre and post period of IFRS

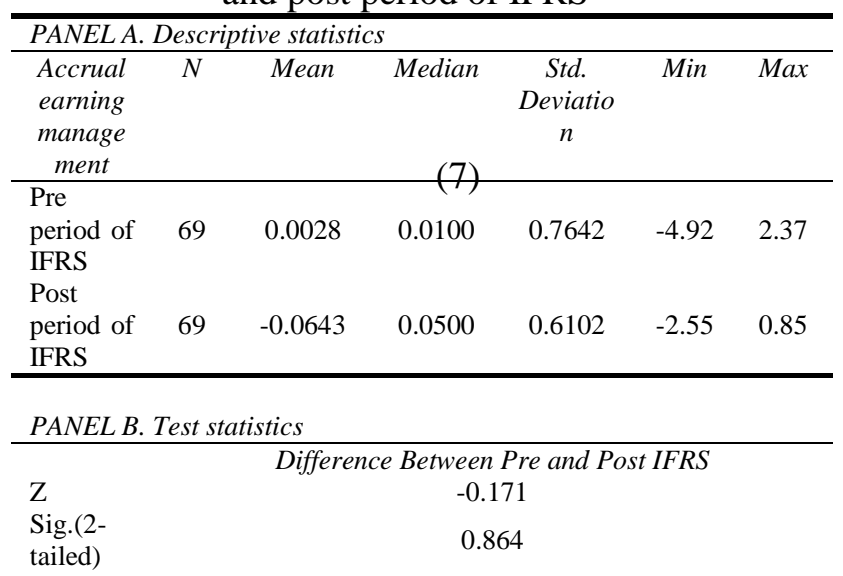

\section{Source: Data Process}

The result of descriptive statistics regarding accrual earnings management and the firm value along with the number of the control variables is presented in Table 3. For the sample of 161 bank-year observations, this research interprets the main variabels used in the regression models. The mean of the firm value 
AKRUAL: Jurnal Akuntansi, volume 10, issue 1, October 2018 (69-84)

(Q) is equal to 1 , it indicates that the mean of market may be valuing the banks which succeed in achieving their planned good performance. the mean of earnings management proxied by discretionary accruals (DA) shows the negative coefficient. It indicates that the mean of banks attempts to manage their earnings using incomedecreasing pattern.

Table 3. Descriptive statistics

\begin{tabular}{lcccccc}
\hline \multicolumn{1}{c}{ Variable } & $N$ & Mean & $\begin{array}{c}\text { Media } \\
n\end{array}$ & Min & Max & $\begin{array}{c}\text { Std } \\
\text { Dev }\end{array}$ \\
\hline $\begin{array}{l}\text { Firm value } \\
\text { (Q) }\end{array}$ & 161 & 1.06 & 1.01 & 0.50 & 1.39 & 0.13 \\
$\begin{array}{l}\text { Accrual } \\
\text { earnings } \\
\text { management }\end{array}$ & & & & & & \\
$\begin{array}{l}\text { (DA) } \\
\text { Corporate }\end{array}$ & 161 & -0.30 & 0.05 & -4.92 & 2.37 & 0.64 \\
$\begin{array}{l}\text { governance } \\
\text { (CG) }\end{array}$ & 161 & -0.01 & -0.19 & -1.97 & 2.99 & 1.00 \\
$\begin{array}{l}\text { Listing } \\
\text { status age }\end{array}$ & & & & & & \\
(LISTING) & 161 & 11.22 & 10.30 & 0.20 & 31.00 & 0.20 \\
$\begin{array}{l}\text { Firm size } \\
\text { (SIZE) }\end{array}$ & 161 & 17.47 & 17.86 & 14.26 & 20.41 & 1.66 \\
IFRS & 161 & 0.57 & 0.57 & 0.00 & 1.00 & 0.49 \\
\hline
\end{tabular}

\section{Source: Data Process}

This research also provides the Pearson correlation coefficient for all of the variables. As can be shown in Table 4, the correlation between firm value and earnings management is positive and significant at the 0.01 level.

Table 4. Pearson correlation

\begin{tabular}{|c|c|c|c|c|c|c|}
\hline & Q & DA & CG & $\begin{array}{l}\text { LIST } \\
\text { ING }\end{array}$ & SIZE & IFRS \\
\hline \multirow{2}{*}{$\begin{array}{l}\text { Q } \\
\text { DA }\end{array}$} & 1 & & & & & \\
\hline & 0.348 & 1 & & & & \\
\hline \multirow[t]{2}{*}{ CG } & & & & & & \\
\hline & 0.160 & 0.088 & .1 & & & \\
\hline LISTING & 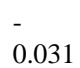 & -0.087 & $\begin{array}{l}0.11 \\
5\end{array}$ & 1 & & \\
\hline SIZE & $-\overline{0.035}$ & -0.035 & $\begin{array}{l}0.17 \\
7^{* *}\end{array}$ & $\begin{array}{l}0.0 \\
59\end{array}$ & 1 & \\
\hline IFRS & $\begin{array}{l}- \\
0.179\end{array}$ & -0.044 & $\begin{array}{l}0.09 \\
9\end{array}$ & $\begin{array}{l}0.2 \\
59^{*}\end{array}$ & $\begin{array}{l}0.0 \\
50\end{array}$ & 1 \\
\hline
\end{tabular}

\footnotetext{
Note. ${ }^{* * * *}$ significant at the 0.01 level; ${ }^{* *}$ significance at the 0.05 level; *significance at the 0.1 level
}

Source: Data Process
As shown in Table 5, the regression result of the fixed effect model is presented. It shows the relationship between accrual earnings management and the firm value including all the observations in the sample. Earnings management proxied by discretionary accrual (DA) shows the positive coefficient of 0.067 and significant at the 0.01 level. For control variables, corporate governance $(\mathrm{CG})$ shows the positive coefficient of 0.020 and significant at the 0.05 level, listing status age (LISTING) shows the positive coefficient of 0.0001 and insignificant, size firm (SIZE) shows the negative coefficient of 0.020 and insignificant, as well as IFRS shows the negative coefficient of 0.047 and significant at the 0.05 level.

Table 5. Regression result

\begin{tabular}{|c|c|c|}
\hline \multirow{2}{*}{ Intercent } & Coefficient & t-statistic \\
\hline & 1.109 & $10.648^{* * * *}$ \\
\hline DA & 0.067 & $4.429^{* * *}$ \\
\hline $\mathrm{CG}$ & 0.020 & $2.030^{* *}$ \\
\hline LISTING & 0.001 & 0.377 \\
\hline SIZE & -0.003 & -0.587 \\
\hline IFRS & -0.047 & $-2.347^{* *}$ \\
\hline $\begin{array}{l}\mathrm{N}=161 \\
\mathrm{R}^{2}=0.17 \\
\text { Adj. } \mathrm{R}^{2}= \\
0.143 \\
\text { F-Statisti } \\
= \\
6.344 * * *\end{array}$ & & \\
\hline $\begin{array}{rr}\text { Note. } & \uparrow \mathrm{L} \\
& \mathrm{d} \\
& \mathrm{L} \\
& \mathrm{s} \\
& * *\end{array}$ & $\begin{array}{l}\text { is income-d } \\
\text { asing; CG } \\
\text { ING is listin } \\
\text { IFRS is dumn } \\
\text { nificant at the } \\
05 \text { level; }{ }^{\text {sigr }}\end{array}$ & $\begin{array}{l}\text { LDA is income- } \\
\text { rate governance; } \\
\text { age; SIZE is firm } \\
\text { gence of IFRS } \\
\text {; s* significance at } \\
\text { at the } 0.1 \text { level }\end{array}$ \\
\hline
\end{tabular}

Source: Data Process

As stated in Table 6, this research provides two model. Model 1 considers the observations with positive discretionary accruals as incomes-increasing pattern to test the hypothesis $2 \mathrm{a}$ and model 2 considers the 
observations with negative discretionary accruals as incomes-increasing pattern to test the hypothesis $2 \mathrm{~b}$. As shown in Table 6, incomeincreasing shows the positive coefficient of 0.114 and significant at the 0.01 level and income-decreasing shows the positive coefficient of 0.067 and significant at the 0.01 level. In model 1 , corporate governance $(\mathrm{CG})$ is also significant at the 0.01 level with the positive coefficient. For the other variables in model 1, firm size (SIZE) and IFRS show significant at the 0.10 level with each negative coefficient of 0.017 and of 0.054 . Moreover, listing status age (LISTING) shows 0.0001 and insignificant. For control variables in Model 2, all are no significant at all level established in the regression model.

Table 6. Regression result for model 1 and model 2

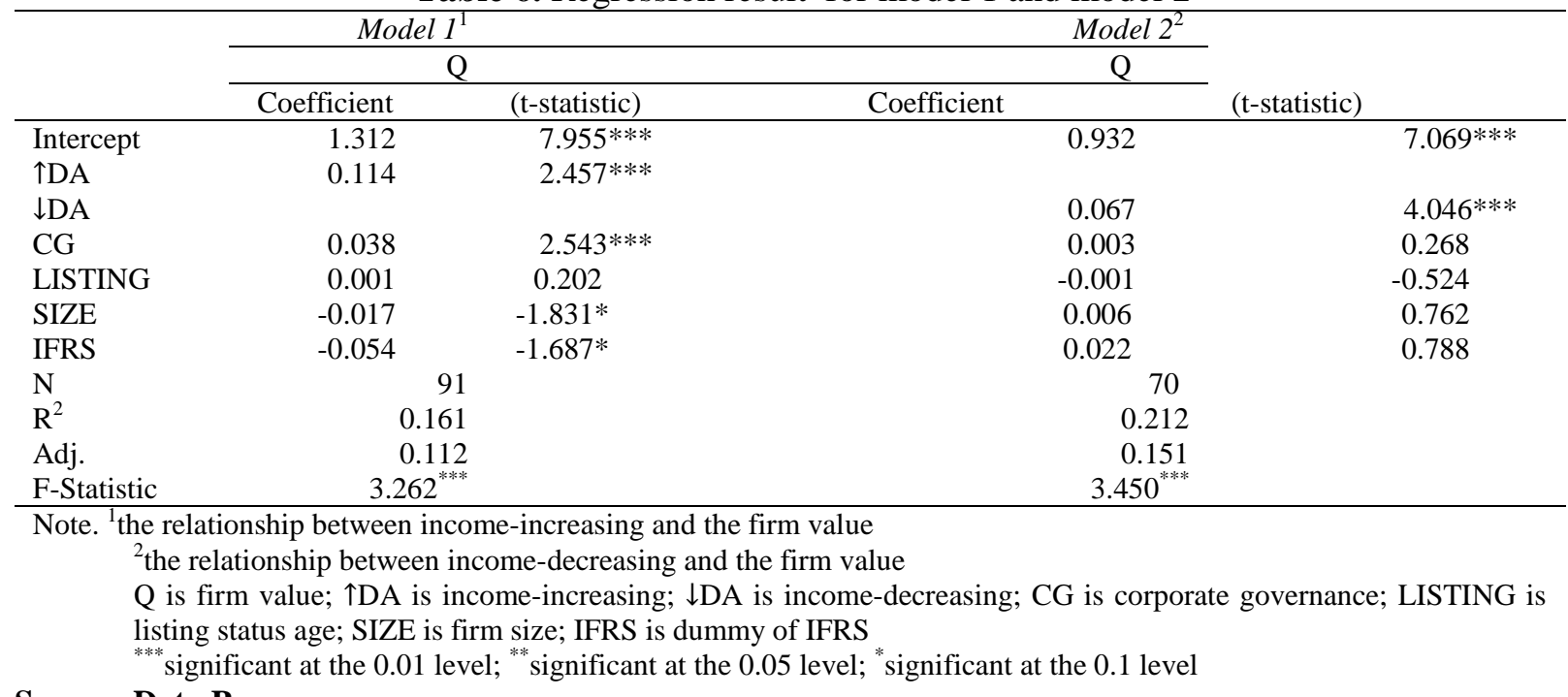

Source: Data Process

After running each of the regression model, the correlation analysis is required to investigate strength each of the patterns in accrual earnings management. Table 7 shows the coefficient correlation between incomeincreasing and the firm value around 0.2 indicating weak correlation and between income-decreasing and the firm value around 0.4 indicating quite strong. However, both patterns have higher correlation than the variables which are corporate governance, listing status age, size firm, and IFRS.

Table 7. Correlations of the variables used in model 1 and model 2

\begin{tabular}{|c|c|c|c|c|c|c|}
\hline & Zero-order & Partial & Part & Zero-order & Partial & Part \\
\hline$\uparrow \mathrm{DA}$ & 0.261 & 0.257 & 0.244 & & & \\
\hline$\downarrow \mathrm{DA}$ & & & & 0.440 & 0.451 & 0.449 \\
\hline CG & -0.007 & 0.022 & 0.020 & -0.024 & -0.065 & -0.058 \\
\hline LISTING & 0.215 & 0.266 & 0.253 & 0.022 & 0.034 & 0.030 \\
\hline SIZE & -0.080 & -0.195 & -0.182 & 0.091 & 0.098 & 0.087 \\
\hline IFRS & -0.135 & -0.180 & -0.168 & 0.030 & 0.095 & 0.085 \\
\hline
\end{tabular}

Note. $\uparrow D A$ is income-increasing; $\downarrow$ DA is income-decreasing CG is corporate governance; LISTING is listing status age; SIZE is firm size; IFRS is dummy convergence of IFRS

Source: Data Process 
AKRUAL: Jurnal Akuntansi, volume 10, issue 1, October 2018 (69-84)

Accrual Earnings Management in Pre and Post Period of IFRS

The examination of accrual earnings management in pre and post period of convergence of IFRS shows that there might be statistically high difference in the mean of accrual earnings management, but it is no significant at all levels established in the research model. It indicates that convergence of IFRS in the Indonesian banking industry has no effect on accrual earnings management. Therefore, the development the hypothesis 1 that there is the difference in the mean for accrual earnings management between pre and post period of convergence of IFRS is rejected. The trend to manage earnings in post period of IFRS is not different with in pre period of IFRS.

The result of testing the hypothesis rejects the expectation. The convergence of IFRS into PSAK 50 and PSAK 55 has been effective and implemented by Indonesian banks for three years, but it does not change the discretionary of managers to employ accrual earnings management. This strenghtens the finding of Santy et al. (2013). At previous research, Santy et al. (2013) found that there is no significant difference in the level of earnings management between pre and post period of the convergence of IFRS and further run additional check by testing the effect of IFRS on the level of earnings management. As a result of their research, IFRS has no effect at all on earnings management.

The rejection of the hypothesis 1 is likely to be justified because earnings management is unaffected by the convergence of IFRS Earnings management could not be superior in Indonesia because it was only convergenced and adjusted with institutional rules so that IFRS is unable to control earnings management. For the efficient earnings management purposes, bank managers trend to provide efficient manners to manage earnings in accordance with accounting policy and judgment so as to anticipate unpredictable financial occurrence in the interest of owners.

\section{Earnings Management and Banking Firm}

Value

In the test of the hypothesis $2 \mathrm{a}$, the result shows that income-increasing has the positive and significant effect on the firm value. It indicates that income-increasing leads to an increase of the firm value. The result of testing hypothesis 2a fulfills the expectation that the firm value increases in income-increasing. Under framework of agency theory in perspective of efficiency, managers engage in earnings management to lead the increase of the firm value. It provides beneficial impacts on the increase of the firm value. For the case of the banking industry, managers engage in incomeincreasing to anticipate unpredictable occurrence which causes the firm value going down. Concerning the result of the test of the hypothesis $2 \mathrm{~b}$, that income-increasing has the positive and significants effect on the firm value. It accepts the development of the hypothesis $2 b$ that the firm value increases in incomedecreasing. It indicates that managers can drive 
the firm value. When the firm value is deemed more going up, managers utilise discretionary accrual through income-decreasing pattern.

Furhermore, the mean of the firm value (Q) of the sample indicates that managers attempt to achieve the planned firm value. It is likely to be achieved using accrual earnings management through income-increasing and income-decreasing. To ensure the fixed effect, this research also tests all the observations of the sample both income-increasing and incomedecreasing. It shows similar inference that the fixed effect is positive and significant with the firm value. Regarding the control variables, corporate governance has the positive and siginificant on the firm value. Indeed, the corporate governance in the banking industry is always considered as an essensial determinant in achieving the strategic goal and a set of corporate value. IFRS also has significant effect on the firm value. After the convergence of IFRS in Indonesia, the firm value in fact decreases.

Overall, accrual earnings management patterns through income-increasing and incomedecreasing have beneficial impact on the increase of the firm value. This result supports the research of Raoli (2013) who reveals that an increase in firm value is associated with incomeincreasing and a decrease in firm value is associated with income-decreasing. Under the framework of agency theory in the efficient perspective of earnings management, bank managers employ accrual earnings management with the purpose of keeping their image of performance and the interest of owners.

\section{CONCLUSIONS}

This research has provided evidences which deal with earnings management phenomenon in the banking industry. Earnings management practice becomes a way to achieve strategic value of the firm. As this research has found no substantial difference in the mean between pre and post period of convergence of IFRS, accrual earnings management enables to be a trend to determine the firm value although switching financial standard. From this efficient earnings management perspective, the result of this research has found beneficial impacts of earnings management on the increase of the firm value. Banks have the efforts to manage the value firm with the purpose of anticipating unpredictable financial occurrence in the interest of shareholders as well as the purpose of keeping good image for themselves. In its patterns, income-increasing and income-decreasing are employed by managers to sustain the positive valuation of the firm. Concerning the correlation analysis to investigate strength each of the patterns on the increase of the firm value, income-decreasing has higher correlation with the firm value than income-increasing. Thus, earnings management through incomedecreasing pattern has highly strong impact on the increase of banking firm value.

The extensive finding is imposed in this research. It has been designed to answer the limitations demonstrated by previous research 
and to reach the extension of earnings management patterns. Moreover, the finding of this research is the proponent of earnings management. The implication of this research is justified that accrual earnings management patterns attempt to induce bank managers to employ their behaviours with the purpose of the efficiency. This is relevant to understand manager's behaviours in employing earnings management to keep their performance seems good in the eyes of principle beside the efficiency of market value as well as shareholders' interest. Finally, in order to provide more implication to the enhancement of literature in terms of earnings management, this research should need more development considering banking profitability.

\section{REFERENCES}

Abaoub, E., Homrani, K. and Gamra, S.B. (2013). Determinants of Earnings Management: Empirical Evidence in the Tunisian Banking Industry. Journal of Business Studies Quarterly, Vol. 4, No. 3, pp. 62-72.

Abdallah, S. (2018). External auditor type, discretionary accruals and investors' reactions. Journal of Accounting in Emerging Economies. doi:10.1108/jaee10-2017-0098

Ahmed, A. S., Takeda, C., \& Thomas, S. (1999). Bank loan loss provisions: a reexamination of capital management, earnings management and signaling effects. Journal of Accounting and Economics, 28(1), 1-25. doi:10.1016/s0165-4101(99)00017-8

Akdogan, Y. E., \& Boyacioglu, M. A. (2014). The effect of corporate governance on firm performance: a case of Turkey. International Journal of Critical Accounting, 6(2), 187. doi:10.1504/ijca.2014.063365
Alishah, S.Z., Butt, S. A. \& Hasan, A. (2009). Corporate Governance and Earnings Management an Empirical Evidence from Pakistani Listed Companies. European Journal of Scientific Research, Vol. 26, No. 4, pp. 624-638.

Anggraita, V. (2012). Dampak Penerapan PSAK 50/55 (Revisi 2006) terhadap Manajemen Laba di Perbankan: Peranan Mekanisme Corporate Governance, Struktur Kepemilikan, dan Kualitas Audit. Paper presented in Accounting National Symposium XV, Banjarmasin, Indonesia.

Ararat, M., Black, B. S., \& Yurtoglu, B. B. (2014). Corporate Governance, Business Groups, and Market Value: Time-Series Evidence from Turkey. SSRN Electronic Journal. doi:10.2139/ssrn.2277768

Beaver, W., Eger, C., Ryan, S., \& Wolfson, M. (1989). Financial Reporting, Supplemental Disclosures, and Bank Share Prices. Journal of Accounting Research, 27(2), 157. doi:10.2307/2491230

Beaver, W. H., \& Engel, E. E. (1996). Discretionary behavior with respect to allowances for loan losses and the behavior of security prices. Journal of Accounting and Economics, 22(1-3), 177206. doi:10.1016/s0165-4101(96)00428-4

Cheng, Q., Warfield, T., \& Ye, M. (2011). Equity Incentives and Earnings Management. Journal of Accounting, Auditing \& Finance, 26(2), 317-349. doi:10.1177/0148558x11401219

Cornett, M. M., McNutt, J. J., \& Tehranian, H. (2009). Corporate governance and earnings management at large U.S. bank holding companies. Journal of Corporate Finance, 15(4), 412-430. doi:10.1016/j.jcorpfin.2009.04.003

Deegan, C. (2007). Australian Financial Accounting, Fifth Edition, McGraw-Hill, Australia.

Dumontier, P., \& Raffournier, B. (2002). Accounting and capital markets: a survey of the European evidence. European Accounting Review, 11(1), 119-151. doi:10.1080/09638180220124761 
Healy, P. M., \& Wahlen, J. M. (1999). A Review of the Earnings Management Literature and Its Implications for Standard Setting. Accounting Horizons, 13(4), 365-383. doi:10.2308/acch.1999.13.4.365

Hussein, S. K., \& Venkatram, R. (2013). Corporate Governance and Firm's Value: An Empirical Analysis of Agri-input Firm in India. International Journal of Commerce, Business and Management, 2 (6), 353-362.

Jensen, M. C., \& Meckling, W. H. (1976). Theory of the firm: Managerial behavior, agency costs and ownership structure. Journal of Financial Economics, 3(4), 305-360. doi:10.1016/0304-405x(76)90026-x

Jiraporn, P., Miller, G. A., Yoon, S. S., \& Kim, Y. S. (2008). Is earnings management opportunistic or beneficial? An agency theory perspective. International Review of Financial Analysis, 17(3), 622-634. doi:10.1016/j.irfa.2006.10.005

Laela, S. F. (2012). Kualitas Laba Dan Corporate Governance: Benarkah Kualitas Laba Bank Syariah Lebih Rendah Dari Bank Konvensional? Jurnal Akuntansi Dan Keuangan Indonesia, 9(1), 22-42. doi:10.21002/jaki.2012.02

Lin, F.-L. (2011). Is earnings management opportunistic or beneficial in Taiwan? International Journal of Economics and Finance, 3(1). doi:10.5539/ijef.v3n1p133

Mansur, H., \& Tangl, A. (2018). The Effect of Corporate Governance on the Financial Performance of Listed Companies In Amman Stock Exchange (Jordan). Journal of Advanced Management Science, 6(2), 97-102. DOI:10.18178/joams.6.2.97-102.

Manzalawy, S.M. and Rwegasira K. (2012). The Practice of Earnings Management in the Middle East Emerging Stock Markets: Why and How is it Done? A Case Study of Egypt. International Journal of Business and Commerce, 2(10), 1-14.

Marchini, P. L., Mazza, T., \& Medioli, A. (2018). Related party transactions, corporate governance and earnings management. Corporate Governance: The International Journal of Business in Society. doi:10.1108/cg-11-2017-0271
Mardnly, Z., Mouselli, S., \& Abdulraouf, R. (2018). Corporate governance and firm performance: an empirical evidence from Syria. International Journal of Islamic and Middle Eastern Finance and Management, 11(4), 591-607. doi:10.1108/imefm-052017-0107

Mostafa, W. (2017). The impact of earnings management on the value relevance of earnings. Managerial Auditing Journal, 32(1), 50-74. doi:10.1108/maj-01-20161304

Omid, A. M. (2012). Type of Earnings Management and the Effects Debt Contracts, Future Earnings Growth Forecast and Sales Growth: Evidence from Iran. School of Doctoral Studies (European Union). Journal, 1(1), 7-16

Oosterbosch, R.V. (2009). Earnings Management in the Banking Industry: The Consequences of IFRS Implementation on Discretionary Use of Loan Loss Provision, Thesis, Erasmus University, Rotterdam.

Rezaei, F., \& Roshani, M. (2012). Efficient or Opportunistic Earnings Management with Regards to the of Firm Size and Corporate Governance Practices. Interdisciplinary Journal of Contemporary Research in Business, 3 (9), 1312-1322.

Raoli, E. (2013). Do Managers Engage In Earnings Management To Support Firm's Market Valuation? Corporate Ownership and Control, 10(2). doi:10.22495/cocv10i2c3art5

Salleh, N.M. N.Z., \& Hassan, M.H.C. (2014). Audit Committee and Earnings Management: Pre and Post MCCG. International Review of Management and Business Research, 3 (1), 307-318.

Santy, P., Tawakkal., \& Pontoh, G.T. (2013). Pengaruh Adopsi IFRS terhadap Manajemen Laba pada Perusahaan Perbankan di Bursa Efek Indonesia. Thesis, Universitas Hasanuddin, Indonesia.

Sayari, S., Omri, A., Finet, A., \& Harrathi, H. (2013). The Impact of Earnings Management on Stock Returns: the Case of Tunisian Firms. International Research Journal of Accounting and Auditing, 1(1), 7-21. 
Scott, W.R. (2009). Financial Accounting Theory, Fifth Edition, Pearson Education, Toronto, Canada.

Tangjitprom, N. (2013). The Role of Corporate Governance in Reducing the Negative Effect of Earnings Management. International Journal of Economics and Finance, 5(3). doi:10.5539/ijef.v5n3p213

Tobing, W.R.L. and Anggorowati, N.I. (2009). Perataan Laba Melalui Penyisihan Penghapusan Aktiva Produktif (PPAP) Sektor Perbankan. Akuntabilitas, 9 (1), 50-62.

Tornyeva, K., \& Wereko, T. (2012). Corporate Governance and Firm Performance: Evidence from the Insurance Sector of Ghana. European Journal of Business and Management, 4 (13), 95-112.

Wijayanti, R., \& Diyanti, V. (2017). Pengaruh Volatilitas Laba, Perataan Laba dan Corporate Governance terhadap Kualitas Laba Bank Syariah dan Konvensional. Jurnal Akuntansi Dan Investasi, 18(1). doi:10.18196/jai.18161

Vajriyanti, E., Widanaputra., \& Asri D.P. (2015). Pengaruh Manajemen Laba Riil pada Nilai Perusahaan dengan Good Corporate Governance sebagai Variabel Pemoderasi. Paper presented in Accounting National Symposium XVIII, Medan, Indonesia. 